\title{
RESEARCH OF MINERAL ADSORBENTS APPLICATION FOR WATER-ALCOHOL SOLUTIONS PURIFICATION IN TECHNOLOGY OF ALCOHOLIC BEVERAGES
}

\author{
Lolita Marynchenko \\ Department of Bioinformatic \\ National Technical University of Ukraine "Igor Sikorsky Kyiv Polytechnic Institute" \\ 37 Peremohy ave., Kyiv, Ukraine, 03056 \\ lolitamar@ukr.net \\ Viktor Marynchenko \\ Department of Biotechnology of fermentation and wine making \\ National University of Food Technologies \\ 68 Volodymyrska str., Kyiv, Ukraine, 01601 \\ marinchenko37@ukr.net \\ Mariana Hyvel \\ PJSC "Ukrainian Tachnology Company" \\ 69 Alisher Navoi ave., Kyiv, Ukraine, 02125 \\ givelm@ukr.net
}

\begin{abstract}
The possibility of using natural mineral adsorbents - clinoptilolite and schungite - in the adsorption purification of water-alcohol solutions of different concentrations was studied using the example of impurities of ethanol of acetaldehyde and ethyl acetate. The feasibility of studying the above-mentioned minerals for the adsorption of simple organic substances is justified. The best concentration of a water-alcohol solution for adsorption of acetaldehyde $80-85 \%$ vol., ethyl acetate- $40 \%$ vol., is experimentally established. The rational duration of phase contact for adsorption of acetaldehyde is from 10 to 20 minutes, for adsorption of ethyl acetate -5 minutes.

An explanation for the dependence of the sorption efficiency on the ethanol content in a water-alcohol solution is proposed based on the known dependencies of the rectification factor on the ethanol concentration. The larger the rectification factor, the less the hydrogen bond of this impurity with ethanol and the easier it is to sorb it from ethanol by mineral adsorbents. The practical and economic feasibility of using the mineral adsorbent clinoptilolite of Ukrainian origin in the preparation of alcoholic beverages instead of imported active coal is shown. It is determined that to purify water-alcohol solutions from aldehydes, which most worsen the taste of alcoholic beverages, it is more expedient to use clinoptilolite as an adsorbent. It is shown that the use of clinoptilolite for the preparation of vodkas from non-standard rectified alcohol will improve the tasting indicators of the final product.
\end{abstract}

Keywords: adsorption, volatile alcohol impurities, quality of ethyl alcohol, zeolites, clinoptilolite, schungite.

\section{Introduction}

One of the key quality problems of alcoholic beverages is the minimum amount of volatile ethanol impurities obtained by fermentation of starch or sugar-containing raw materials and released during the process of distillation. The main among such impurities are aldehydes, higher alcohols, organic acids and esters, methanol. Some impurities can be removed by passing a water-alcohol solution through a column of activated carbon.

However, this technology of vodka preparation has a number of drawbacks, above all, the price of active coal imported to Ukraine from Russia. It is also flammability, the possibility of catalytic oxidation and esterification reactions, i. e. the formation of new impurities and inefficiency, for example, in the sorption of esters.

Therefore, the search for new effective adsorbents for purification from volatile impurities of ethanol is an urgent task both from a scientific and practical point of view. Dispersion of zeolites allows to consider natural clay minerals as potentially possible adsorbents and for purification of water-alcohol solutions. This assumption is due to reports on the effectiveness of using different 
types of zeolites for the sorption of small-sized simple chemicals. For example, is the separation of carbon dioxide from flue gases [1], water from natural methane or biogas [2, 3], separation of complex mixtures (methane, carbon dioxide, hydrogen sulfide, water vapor) $[3,4]$. In addition, the efficiency of wastewater or wine purification from heavy metals and nitrates is shown [5-7].

Thus, the study of the possibility of using zeolites to purify water-alcohol solutions from ethanol-related volatile impurities is the goal of this research.

\section{Materials and Methods}

Zeolites in structure are a complex tetrahedral structure in which the main silicon or aluminum atom is bound by four oxygen atoms. Within the chains of such structures, adsorption voids are formed, which can be filled with water or other small substances, which causes the use of zeolites as adsorbents. To do this, before use, the zeolites are dried by removing water. However, the possibility of adsorption is due not so much to the size of the pores as to the size of the input windows, which depends on the crystal lattice, the number of oxygen atoms, and the spatial orientation. Thus, it is the critical size of the molecules that is decisive for the absorption of a particular substance. In addition, active anionic centers are located on the surface of the aluminosilicate skeleton of these structures, the excess charge of which is compensated by the cations of sodium, potassium, calcium, and magnesium. The presence of charge is an additional factor of adsorption and/or ion-exchange capacity [8].

Reserves of natural mineral adsorbents such as bentonite, hydromica, montmorilonite, palygorskite, saponite, clinoptilolite, etc., in Ukraine estimate more than 1 billion tons [9]. Zeolites of the Sokirnitsa deposit can be used for the purification of sewage, in animal husbandry, poultry farming, fish farming, and plant growing $[10,11]$. This, as well as the absence of extraneous odors and flavors, which could spoil the organoleptic characteristics of food raw materials, products or water, allows to consider these minerals for use in the food industry.

One of the most common minerals of soils and bottom sediments - clinoptilolite - found in Asia, South Africa, Australia, North and South America. In Europe, clinoptilolite is common in Hungary, Italy, Romania, Slovakia, Slovenia, Turkey, Ukraine and the West of Russia [12]. The ion-exchange capacity of clinoptilolite is due to the high surface charge, the crystal-chemical formula of which $(\mathrm{Na}, \mathrm{K})_{6}\left[\mathrm{Al}_{6} \mathrm{Si}_{30} \mathrm{O}_{72}\right]_{20} \mathrm{H}_{2} \mathrm{O}$ (per unit cell) and $\left|(\mathrm{Na}, \mathrm{K})_{0,17}\left(\mathrm{H}_{2} \mathrm{O}\right)_{0,56}\right|\left[\mathrm{Al}_{0,17} \mathrm{Si}_{0,83} \mathrm{O}_{2}\right]$ (normalized to $\left.\left[(\mathrm{Al}, \mathrm{Si}) \mathrm{O}_{2}\right]\right)[13]$. Despite the possible partial replacement of sodium ions by potassium, magnesium or sodium ions, which depends on the geology of the occurrence of ores, the inequality $(\mathrm{Na}+\mathrm{K})>(\mathrm{Ca}+\mathrm{Mg})$ is characteristic for clinoptilolite. The thermal stability of the Ukrainian zeolite at the Sokirnitsa deposit $\left(850^{\circ} \mathrm{C}\right)$ is sufficient for the possibility of using clinoptilolite for technological purposes - there have been no significant changes in its structure. Exceeding the ratio of silicon to aluminum for the structure is insignificant - 3.84-4.13. At the same time, a decrease in this ratio leads to a change in the size and shape of the unit cell, the parameters of which are normally within the limits of, nm: 1.77:1.80:0.74. Stretching in one direction and compression in the other leads to a change in the configuration of the channels, which take the form of an ellipsoid. The normal size of the input windows of crystal lattices is about $0.35 \mathrm{~nm}$ [14].

Schungite rocks are found in Karelia (Russia) and Bulgaria. The structural basis of the carbon part of this natural mineral is the globule-fullerene-like formations of 10 to $30 \mathrm{~nm}$ in size [15]. The fullerene shell (closed or composed of fragments) consists of smoothly curved packets of carbon layers that form a nanoscale pore. Globules differ in form and size, which depends, in the main, on the number of carbon atoms (from tens to hundreds). The thickness of the spherical shell of a fullerene molecule consisting of 60 carbon atoms is $\sim 0.1 \mathrm{~nm}$, the molecular radius is $0.357 \mathrm{~nm}$. The average distance between layers of more ordered carbon is $0.34 \mathrm{~nm}$ on the surface of microcrystals, in layers of a more complex structure this size varies from 0.2 to $0.5 \mathrm{~nm}$.

Mineral components are represented by finely dispersed crystals, nanocrystals and layered inclusions. The main mineral part of the schungite is represented by magnesium silicates of the type: $3 \mathrm{MgO} \times 4 \mathrm{SiO}_{2} \times 6 \mathrm{H}_{2} \mathrm{O}$ (hydrated talc) and $3 \mathrm{MgO} \times 2 \mathrm{SiO}_{2} \times 6 \mathrm{H}_{2} \mathrm{O}$ (hydrated serpentine). There is also free $\alpha-\mathrm{SiO}_{2}$ (quartz), $\alpha-\mathrm{Fe}_{2} \mathrm{O}_{3}$ (hematite), $\mathrm{TiO}_{2}$ (rutile), $8 \mathrm{MgO} \times 4 \mathrm{SiO}_{2} \times \mathrm{Mg}(\mathrm{F}, \mathrm{OH}$ ) (clinohumite), $\alpha-\mathrm{Al}_{2} \mathrm{O}_{3}$ (corundum) and $\alpha-\mathrm{CrO}_{3}$ (eskolaite) [ 15]. 


\section{1. Experimental procedures}

To establish a certain fractional composition of the zeolite, sieves with different hole diameters were used, which were a set of five sieves with holes 1, 2, 3, 4 and $5 \mathrm{~mm}$ in diameter. Adsorbents were poured into the upper sieve, which was covered with a lid, shaken violently and the minerals were sieved to different fractions. A fraction of 2-3 $\mathrm{mm}$ was used for the studies.

Before use, the dispersed minerals were weighed and dried in СЭШ-1 drying box (manufactured in the USSR) at a temperature of $120{ }^{\circ} \mathrm{C}$ for 12 hours. Such parameters were chosen to ensure that water is removed from the adsorbent pores. The dried bunks with adsorbent weights were held in the desiccator for $30 \mathrm{~min}$ before cooling to room temperature, and then adsorbers were filled with adsorbents or stored in closed vessels.

Each fraction was stored separately in a glass vessel sealed with a ground glass stopper.

To carry out the research, a laboratory unit was created by the authors (Fig. 1), which is an adsorption column 3 filled with an adsorbent 4 laid on a piece of cotton with a height of not more than $1 \mathrm{~cm}$. Above, the adsorbent is also covered with a piece of cotton wool to the level of the drain tube. In the lower part of the adsorption column, water-alcohol solutions of different concentrations were fed from the pressure collector 1 . The different contact times of the water-alcohol solution with the adsorbent were provided by a different solution delivery rate of 3 to $35 \mathrm{ml} / \mathrm{min}$, which was regulated by the valve 2 . The test samples were taken to a collecting receptacle (measuring cylinder) 5 fixed by a clip 6 on a support 7 from the top of the adsorption column. The studies were carried out at room temperature, that is, $20-22{ }^{\circ} \mathrm{C}$. The first $150 \mathrm{ml}$ of a water-alcohol solution leaving the adsorption column was poured and only after that a sample was taken.

Parameters of the adsorption column: column height $\mathrm{H}=0.45 \mathrm{~m}$; the internal diameter of the column is $\mathrm{d}_{\text {in }}=0.024 \mathrm{~m}$. Then the volume of the column is:

$$
\mathrm{V}=\frac{\pi \cdot \mathrm{d}_{\mathrm{in}}^{2}}{4} \cdot \mathrm{H}
$$

$$
\mathrm{V}=\frac{3,14 \cdot 0,024^{2}}{4} \cdot 0,45=0,203 \cdot 10^{-3} \mathrm{~m}^{3}=203 \mathrm{ml}
$$

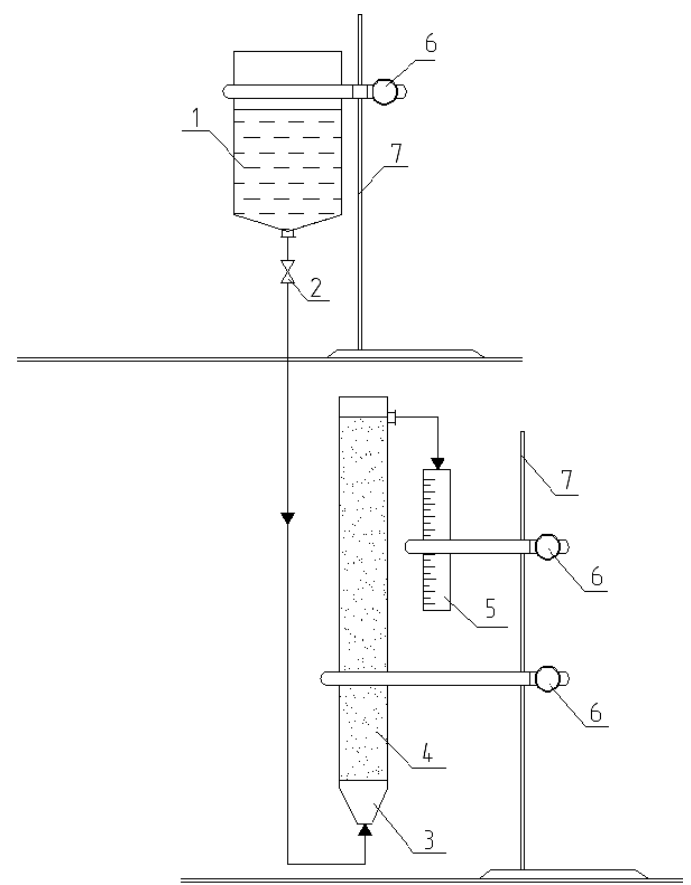

Fig. 1. Laboratory unit for purification of water-alcohol solutions: 1 - pressure collector; 2 - control valve; 3 - adsorption column; 4 - adsorption material; 5 - measuring cylinder;

$$
6 \text { - clip; } 7 \text { - support }
$$


To prepare water-alcohol solutions of different concentrations, alcoholimetric tables were used, taking into account the temperature and contraction corrections that occurred when the alcohol or aqueous alcohol solutions were diluted [16]. To quickly determine the concentration of water-alcohol solutions, areometer-alcoholometers were used, which were immersed in a vertical cylinder filled with alcohol with an ethyl rectified concentration of $96.8 \%$ vol., and a water-alcohol mixture with concentrations of 40, 50 and $80 \%$ vol. To determine the correction for temperature, mercury laboratory thermometers were used [17].

The concentration of impurities of aldehydes and esters by the example of acetaldehyde and ethyl acetate in control and test samples was determined by gas chromatography on a gas chromatograph "Crystal 2000" (Chromatec, Russia) [18]. As control, ethyl alcohol was rectified with a concentration of $96.8 \%$ vol., and water-alcohol solutions diluted to a concentration of 40, 50 and $80 \%$ vol., which were not subjected to adsorption purification in a laboratory plant.

The average arithmetic value of the components of two parallel measurements for the concentration of the microcomponent in the control and test samples was accepted, the permissible difference between which did not exceed the norm of the operational control of convergence $r_{n}$ at $\mathrm{P}=0.95 \%, \mathrm{n}=2\left(\mathrm{r}_{\mathrm{n}}\right.$ - operative control of convergence, $\mathrm{P}-$ confidence coefficient, $\mathrm{N}-$ the number of parallel measurements). For ethyl acetate and acetaldehyde at their mass concentration in recalculation on anhydrous alcohol, $\mathrm{mg} / \mathrm{dm}^{3}$, from 0.5 to $10.0-r_{n}=15 \%$; from 10.0 to $50.0-r_{n}=10 \%$. The results that exceeded these values, which are given in the normative document [19] for the determination of the content of microcomponents by the gas chromatographic method, were discarded.

The study was conducted with non-standard ethyl alcohol (non-compliance with the normative document on the indices of the concentration of aldehydes and esters). According to the normative document [20], the mass concentration of aldehydes in terms of acetic aldehyde in anhydrous alcohol should not exceed $4 \mathrm{mg} / \mathrm{dm}^{3}$, the mass concentration of esters, calculated per acetic-ethyl ester in anhydrous alcohol, should not exceed $5 \mathrm{mg} / \mathrm{dm}^{3}$ for an alcohol of the grade "Higher purification".

Adsorption of aldehydes was investigated using acetaldehyde as an example, the content of which is usually $90 \%$ or more of the total aldehyde in rectified ethyl alcohol. The adsorption of the esters was determined by the example of ethyl acetate as the main component of the esters. The results were calculated in $\mathrm{mg} / \mathrm{dm}^{3}$ of anhydrous alcohol.

\section{Results}

The dynamics of acetaldehyde adsorption by clinoptilolite from water-alcohol solutions of different concentrations showed the same trend. With an increase in the duration of phase contact to 5-10 $\mathrm{min}$, the concentration of this impurity in the outgoing solution decreased, but then began to increase again. Thus, the sorption process must be carried out fairly quickly, since an increase in the duration of the contact seems to cause either desorption of acetaldehyde or the oxidation of ethanol.

However, acetaldehyde sorption was different for different concentrations of water-alcohol solutions: the best results were noted for a concentration of $80 \%$ vol.; the acetaldehyde concentration decreased by almost $63 \%$ (from 4.47 to $1.67 \mathrm{mg} / \mathrm{dm}^{3}$ ). To concentrate the water-alcohol solution $50 \%$ vol., the lowest value was fixed at the level of $2.3 \mathrm{mg} / \mathrm{dm}^{3}$, for a concentration of $96.8 \%$ vol., $-2.58 \mathrm{mg} / \mathrm{dm}^{3}$, for a concentration of $40 \%$ vol., $-3.08 \mathrm{mg} / \mathrm{dm}^{3}$.

Thus, it is least expedient to carry out purification from a water-alcohol solution with a concentration of $40 \%$ vol. However, for all concentrations, it has been shown that it is possible to improve the acetaldehyde concentration to a standard value.

In the study of the dynamics of the aldehydes adsorption process by schungite on acetaldehyde, depending on the concentration of water-alcohol solutions and the duration of phase contact, the quality of the samples did not meet the requirements of the standard for the concentration of aldehydes [20] $-8.28 \mathrm{mg} / \mathrm{dm}^{3}$. The sorption of acetaldehyde by schungite occurred most intensively 
during the first 5-10 minutes. But a further increase in the transmission time of the water-alcohol solution did not cause such an obvious process of increasing the concentration of acetaldehyde, as with sorption by clinoptilolite. The most effective acetaldehyde was adsorbed by schungite also from a water-alcohol solution with a concentration of $80 \%$ vol., - up to $6.37 \mathrm{mg} / \mathrm{dm}^{3}$ or more than $25 \%$. It should be noted that up to duration of contact of $20 \mathrm{~min}$, the scatter of data on the content of acetaldehyde after sorption for concentrations of 80,50 and $96.8 \%$ vol., was within the error of experience.

In the next series of studies, the content of ethyl acetate was analyzed, the concentration of which among esters is highest in rectified ethyl alcohol and alcoholic beverages.

Analysis of the sorption of ethyl acetate by clinoptilolite shows a completely different distribution of the results for different concentrations of water-alcohol solutions. The results showed that the concentration of $40 \%$ vol., is preferable (decrease from 3.4 to $0.6 \mathrm{mg} / \mathrm{dm}^{3}$ ), and an increase in the concentration of ethanol in the purified solution impaired the efficiency of the process. It is possible that the optimal duration of phase contact may be time, even less than 5 minutes. However, it was technically impossible to provide such conditions at such column height. And with increasing contact time up to 60 minutes, the concentration of ethyl acetate almost reached the value in the control sample, which may indicate the presence of catalytic reactions.

The results of sorption of ethyl acetate by schungite have a wider spread of indices for different concentrations of water-alcohol solutions, but the efficiency of sorption has repeated the tendency of sorption by clinoptilolite. Increase the dilution of the water-alcohol solution to a concentration of $40 \%$ vol., gave the best results - the content of ethyl acetate after 5 minutes of the process decreased by almost 5 times. Thus, it can be state that it is possible to achieve the normative indices of the concentration of ethyl acetate by a schungite adsorption in a water-alcoholic solution of $40 \%$ vol.

To calculate the economic efficiency of the use of zeolites for purification of aqueous-alcoholic solutions, the initial data was taken: the working month is 24 days, the one-change operation mode, and the productivity is 20,000 decalitres (dkl) per month. Then the daily capacity of the adsorption unit is:

$$
\mathrm{G}=\frac{20000}{24}=833,3(\mathrm{dkl} / \mathrm{day})
$$

and the adsorber capacity per change

$$
\mathrm{G}_{1}=\frac{833,3}{8}=104,2 \text { (dkl/change) }
$$

The adsorber volume at $\mathrm{d}=0,7 \mathrm{~m}, \mathrm{~h}=4 \mathrm{~m}$ is:

$$
\mathrm{V}=\frac{\pi \mathrm{D}^{2}}{4} \mathrm{~h}=\frac{3,14 \cdot 0,7^{2}}{4} \cdot 4=1,54\left(\mathrm{~m}^{3}\right) .
$$

If we assume that for purification of $3 \mathrm{dkl}$ of sorting prior to ensuring the normative indices, it is necessary to have $0.4 \mathrm{~kg}$ of zeolites, then the flow will be:

$$
\mathrm{m}=\frac{104,2 \cdot 0,4}{3}=13,9(\mathrm{~kg} / \mathrm{day})
$$

When the adsorber is filled to $80 \%$ (taking into account the breakthrough), the volume of the adsorbent will be:

$$
\mathrm{V}_{\mathrm{ads}}=1,54 \cdot 0,8=1,2\left(\mathrm{~m}^{3}\right)
$$


For a bulk adsorbent mass of $1100 \mathrm{~kg} / \mathrm{m}^{3}$, the mass of the zeolite in the adsorber:

$$
\mathrm{m}_{\mathrm{ads}}=1100 \times 1,2=1320(\mathrm{~kg})
$$

The number of changes of the adsorber before regeneration of the adsorbent will be:

$$
\tau_{\mathrm{sch}}=\frac{\mathrm{m}_{\mathrm{ads}}}{\mathrm{m}}=\frac{1320}{13,9}=95
$$

Annual consumption of zeolite:

$$
\begin{gathered}
1320 \mathrm{~g} \rightarrow 95 \text { changes; } \\
\mathrm{m}_{\mathrm{c}} \rightarrow 288 \text { changes; } \\
\mathrm{m}_{\mathrm{sch}}=\frac{1320 \cdot 288}{95}=4000(\mathrm{~kg}) \approx 4(\mathrm{t}) .
\end{gathered}
$$

Annual cost of the adsorbent:

$$
\mathrm{B}=1500 \cdot 4=6000(\mathrm{UAH}),
$$

where $1500 \mathrm{UAH}$ - the cost of 1 ton of zeolite [21].

At a consumption of active coal per year about 4.2 tons

$$
\mathrm{m}_{\text {coal }}=\frac{350 \cdot 240000}{20000}=4200(\mathrm{~kg}) \approx 4,2(\mathrm{t})
$$

where 350 - the mass of active coal necessary for purification of 20,000 dkl; 240000 - annual plant productivity, dkl, at a cost of active coal $35000 \mathrm{UAH}$ [22] the annual cost will be 147 thousand UAH.

Thus, the economic efficiency of using zeolites instead of active coal will be about 140 thousand UAH or more than 5 thousand USD. To reduce the consumption of zeolites can also be the use of regeneration, since natural zeolites are wear-resistant.

It is also known about the use of natural zeolites for extraction of ethanol from dilute ethanol-water solutions [23] and dehydration of bioethanol [24, 25]. The possibility of sorption of primary alcohols C1-C4 [26, 27], as well as isoamylol, isobutanol, isopropanol, [27] is also shown. The conclusion in [26] is that the stability of adsorbed alcohols is controlled by van der Waals dispersion interactions and steric zeolite limitations, which destabilize the local formation of hydrogen bonds.

\section{Conclusions}

Analysis of the research results on the possibility of using mineral adsorbents (clinoptilolite and schungite) for purification of water-alcohol solutions from impurities shows the practical and economic feasibility of using natural zeolites.

The best concentration of a water-alcohol solution for adsorption of acetaldehyde is $80-85 \%$ vol.; ethyl acetate is $40 \%$ vol. This is explained by the lowest energy of hydrogen bonds with ethanol, indirectly determined from the dependence of the rectification factor on the ethanol content of the solution.

The rational duration of phase contact for adsorption of acetaldehyde is from 10 to 20 minutes, for adsorption of ethyl acetate -5 minutes.

To purify water-alcohol solutions from aldehydes, which most worsen the organoleptic characteristics of alcoholic beverages, it is more appropriate to use clinoptilolite. It can also allow to achieve the normative parameters of vodka made from non-standard rectified alcohol. 
A problematic issue of using clinoptilolite can be its spraying and the ingress of small particles into the product. And although manufacturers guarantee the safety of this adsorbent for a person (such as active coal), an additional filter must be provided. This will help preserve the marketable condition of the product.

\section{References}

[1] Xiao, P., Zhang, J., Webley, P., Li, G., Singh, R., Todd, R. (2008). Capture of $\mathrm{CO}_{2}$ from flue gas streams with zeolite $13 \mathrm{X}$ by vacuum-pressure swing adsorption. Adsorption, 14 (4-5), 575-582. doi: 10.1007/ s10450-008-9128-7

[2] Li, Y., Yi, H., Tang, X., Li, F., Yuan, Q. (2013). Adsorption separation of $\mathrm{CO}_{2} / \mathrm{CH}_{4}$ gas mixture on the commercial zeolites at atmospheric pressure. Chemical Engineering Journal, 229, 50-56. doi: 10.1016/ j.cej.2013.05.101

[3] Farag, H. A. A., Ezzat, M. M., Amer, H., Nashed, A. W. (2011). Natural gas dehydration by desiccant materials. Alexandria Engineering Journal, 50 (4), 431-439. doi: 10.1016/j.aej.2011.01.020

[4] Lively, R. P., Chance, R. R., Kelley, B. T., Deckman, H. W., Drese, J. H., Jones, C. W., Koros, W. J. (2009). Hollow Fiber Adsorbents for CO2Removal from Flue Gas. Industrial \& Engineering Chemistry Research, 48 (15), 7314-7324. doi: 10.1021/ie9005244

[5] Bezdieniezhnykh, L. Ya., Aleksieieva, T. M. (2009). Mozhlyvosti adsorbtsiinoho ochyshchennia stichnykh vod vid ioniv vazhkykh metaliv. Ekolohichna bezpeka, 2 (6), 54-57.

[6] Nechytailo, L. Ya., Ersteniuk, H. M. (2015). Efektyvnist vykorystannia pryrodnoho sorbentu dlia ochyshchennia pytnoi vody vid nitrat-yoniv. Naukovi zapysky TNPU. Seriya:Khimiya, 22, 24-28.

[7] Luchian, C. E., Colibaba, C., Niculaua, M., Codreanu, M., Cotea, V. V. (2015). Innovative materials in winemaking. BIO Web of Conferences, 5, 02023. doi: 10.1051/bioconf/20150502023

[8] Melnyk, V. M., Melnyk, V. P., Mank, V. V. et. al. (2002). Pat. No. 51497 UA. Sposib deghidrataciyi etylovogho spyrtu. MPK A7 C07C7/13. No. 2002042978; declareted: 12.04.2002; published: 15.11.2002, Bul. No. 11.

[9] Mineral'ni resursy Ukrayiny (2014). Kyiv: Derzhavne naukovo-vyrobnyche pidpryyemstvo «Derzhavnyy informatsiynyy heolohichnyy fond Ukrayiny», 270.

[10] Tekhnicheskaya dokumentaciya. Zakarpatskiy ceolitovyi zavod. Available at: http://www. dpzzz.com/ru/docs.htm

[11] Shushkov, D. A., Kotova, O. B., Naumko, I. M. (2011). Svoystva i primenenie klinoptilolitovyih tufov Zakarpatya i analtsimsoderzhaschih porod Timana. Zapiski Ukrayinskogo mineralogichnogo tovaristva, 8, 226-229.

[12] Ambrozova, P., Kynicky, J., Urubek, T., Nguyen, V. (2017). Synthesis and Modification of Clinoptilolite. Molecules, 22 (7), 1107. doi: 10.3390/molecules22071107

[13] Bakakyn, V. V., Seriotkyn, Yu. V. (2009). Unificirovannye formul'nye i ob»emnye harakteristiki v sravnitel'noy kristallohimii prirodnyh ceolitov. Zhurnal strukturnoi khymii, 50 (7), 123-130.

[14] Hrechanovskaia, E. E. (2010). Metrika elementarnoi yacheiky i otnoshenye Si/Al v tseolytakh riada heilandyt-klynoptylolyt Sokyrnytskoho mestorozhdenyia (Zakarpate, Ukrayna). Mineralohichnyi zhurnal, 32 (4), 12-22.

[15] Ignatov, I., Mosin, O. V. (2014). The structure and composition of carbonaceous fullerene containing mineral shungite and microporous crystalline aluminosilicate mineral zeolite. Mathematical model of interaction of shungite and zeolite with water molecules. Advances in Physics Theories and Applications, 28, 10-21.

[16] Yanchevskyi, V. K., Oliynychuk, S. T., Kravchuk, Z. D. et. al. (2002). Tablicy spirtometricheskie. Kyiv: UkrNYYspyrtbyoprod, 592.

[17] Instrukciya po tekhnologhicheskomu i mikrobyologhicheskomu kontrolyu spirtovogho proizvodstva (2008). Moscow: VNIIPBT, 399.

[18] Carev, N. Y., Carev, V. Y., Katrakov, Y. B. (2000). Praktycheskaya gazovaya khromatoghrafiya. Barnaul: AGhU, 156. 
[19] DSTU 4222:2003. Natsional'nyi standart Ukrayiny. Horilky, spyrt etylovyi ta vodno-spyrtovi rozchyny. Hazokhromatohrafichnyi metod vyznachannya vmistu mikrokomponentiv (2004). Kyiv: Derzhspozhyvstandart Ukrayiny, 12.

[20] DSTU 4221:2003. Spyrt etylovyi rektyfikovanyi. Tekhnichni umovy (2004). Kyiv: Derzhspozhyvstandart Ukrayiny, 10.

[21] Tseolit. Available at: https://sokirnitskij-tseoltovij-zavod.prom.ua/g6619229-tseolt

[22] Aktivirovannyi ugol (marka BAU-A, BAU-MF, DAK, OU-A). Available at: http://snabhim.com. ua/vodoochistka/aktivirovannyj-ugol-bau-a.html?gclid=CjwKEAjwqcHLBRCq5uHTpLL12FISJAD6PgDIDGKtUzxLGaueJyUVFM-58u-Xr-c-xE2-msM7QO8J-xoC8Mjw_wcB

[23] Zhang, K., Lively, R. P., Noel, J. D., Dose, M. E., McCool, B. A., Chance, R. R., Koros, W. J. (2012). Adsorption of Water and Ethanol in MFI-Type Zeolites. Langmuir, 28 (23), 8664-8673. doi: 10.1021/ la301122h

[24] Kontar, O. Ya., Valievakhin, H. M., Haleiev, E. R., Dokhov, O. I. (2014). Pat. No. 105707 UA. Sposib otrymannia spyrtu etylovoho znevodnenoho. MPK A7 C07C7/13. No. a201300030; declareted: 02.01.2013; published: 10.02.2014, Bul. No. 11 .

[25] Onuki, S., Koziel, J. A., (Hans) van Leeuwen, J., Jenks, W. S., Grewell, D., Cai, L. (2008). Ethanol production, purification, and analysis techniques: a review. 2008 Providence, Rhode Island. doi: 10.13031/2013.25186

[26] Nguyen, C. M., Reyniers, M.-F., Marin, G. B. (2010). Theoretical study of the adsorption of C1-C4 primary alcohols in H-ZSM-5. Physical Chemistry Chemical Physics, 12 (32), 9481-9493. doi: 10.1039/ $\mathrm{c} 000503 \mathrm{~g}$

[27] Marynchenko, V. P., Marynchenko, L. V., Fil, O. V. (2014). Ochyshchennia vodno-spyrtovykh rozchyniv vid vyshchykh spyrtiv mineralnymy adsorbentamy. Naukovi pratsi NUKhT, 20 (5), 214-219. 